\title{
Strategies to Increase Discipline in Distance Learning
}

\author{
Septi Wahyu Estiyani ${ }^{1 *}$, Fitri Nur Mahmudah ${ }^{2}$ \\ 1,2 Prodi Manajemen Pendidikan, Universitas Ahmad Dahlan, Yogyakarta \\ *Email: septiwahyu15@gmail.com¹, fitri.mahmudah@mp.uad.ac.id²
}

\begin{abstract}
Proses pembelajaran jarak jauh yang dilakukan oleh guru dan siswa menjadi tantangan tersendiri terutama terkait motivasi belajar dan disiplin belajar siswa. Penelitian ini bertujuan untuk menganalisis penguatan belajar dalam upaya meningkatkan disiplin belajar siswa dimasa pandemi. Metode yang digunakan dalam penelitian ini adalah kualitatif dengan pendekatan studi kasus. Prosedur penelitian menggunakan Miles dan Huberman. Teknik pengambilan data menggunakan observasi dan wawancara. Analisis data dilakukan dengan berbantuan software Atlas.ti versi 8. Hasil penelitian ini menunjukkan bahwa pentingnya respon siswa, penguatan motivasi dari orang tua, dan fokus belajar siswa. Faktor-faktor tersebut merupakan beberapa hal dari hasil penelitian yang berkaitan dengan tiga fokus penting yaitu strategi penguatan belajar, respon penguatan, dan pembelajaran jarak jauh. Berdasarkan hasil penelitian, dapat disimpulkan bahwa orang tua sangat dibutuhkan oleh anak dalam proses pembelajaran jarak jauh di masa pandemi seperti sekarang. Orang tua juga harus mampu mendisiplinkan anak selama kegiatan belajar berlangsung. Dalam upaya mendisiplinkan anak orang tua memberikan penguatan agar anak lebih semangat dalam belajar. Penguatan yang diberikan oleh orang tua yaitu penguatan verbal dan ada juga yang dalam bentuk nonverbal.
\end{abstract}

Kata Kunci: Disiplin Belajar, Pembelajaran Jarak Jauh

\section{Abstract}

The distance learning process carried out by teachers and students is a challenge, especially related to learning motivation and student learning discipline. This study analyzes strengthening learning to improve student learning discipline during the pandemic. The method used in this research is qualitative with a case study approach. The research procedure uses Miles and Huberman. Data collection techniques using observation and interviews. Data analysis was carried out using Atlas.ti software version 8. The results of this study indicate the importance of student response, strengthening parents' motivation, and student learning focus. Some of the research results related to three important focuses: strategies to improve learning, respond to improvements, and distance learning. Based on the study results, it can be seen that children in the distance learning process very much need parents during a pandemic like now. Parents must also be able to discipline their children during learning activities. To discipline children, parents encourage children to be more enthusiastic in learning. Reinforcement provided by parents is to strengthen verbally and some are in the form of nonverbal.

Keywords: Learning Discipline, Distance Learning Process

\section{INTRODUCTION}

Distance learning is learning that uses online media as the main tool for learning but must pay attention to the availability of tools to access distance learning so that it will be able to minimize obstacles in its implementation. Distance learning is a learning activity in which participants or students do not regularly gather to receive teaching from the teacher. Students get teaching from the teacher online. The teacher sends materials for learning through platforms such as WhatsApp groups, YouTube, or other electronic media. The distance learning application learning system is not carried out in the classroom, so there is no direct face-to-face interaction between teachers and students. Advances in information and communication technology in education have created a trend from traditional face-to-face teaching to distance

\footnotetext{
${ }^{*}$ Corresponding author.

Received June 27, 2021; Accepted July 27, 2021; Available online October 25, 2021

This is an open access article under the CC BY-SA license. Copyright $@ 2021$ by Author. Published by Universitas Pendidikan Ganesha.
} 
learning that can be accessed through media such as laptops, multimedia and the internet without being limited by distance, location and time for anyone who may need it (Alqudah et al., 2020; Hignasari \& Supriadi, 2020; Widiastuti et al., 2020).

In the industrial era 4.0, people are expected to use technology in online learning to run well and effectively. Distance learning is a concept that includes teaching and learning activities in the cognitive, psychomotor, and affective domains of an individual learner and organizational supporter. It is characterized by non-verbal communication and can be done anywhere and anytime, making it attractive to adults with professional and social commitments. Distance learning people who are physically separated from the teacher have a planned and guided learning experience. Distance learning using digital tools can be defined as electronic technology to deliver, support, and enhance learning (Latifah \& Prastowo, 2020; Santosa et al., 2020; Wang et al., 2020; Widyantara \& Rasna, 2020). Teaching involves communication between students and teachers utilizing online content barriers to implementation and use of distance learning may be related to limited experience and knowledge in using digital tools when conducting learning activities. Students pursuing open and distance learning rely heavily on information, communication, and technology (ICT) tools for online facilitation and other supporting learning activities.

When students are required to stay at home, as is the case during the current COVID19 pandemic, parents need good parenting skills and a good level of education. Apart from monitoring the temperament and performance of their children, parents should strive to satisfy their children's educational needs as effectively as possible. Parents seem to have many personal barriers that they feel affect the standard and quality of their children's distance learning experience. It is clear that the lack of parental training on how to handle distance learning techniques and materials and the absence of trained personnel to assist them are major concerns. Not all parents can handle the technology needed for distance learning, which prevents them from enabling efficient use at home. Finally, the parents raised the issue of their qualifications. Parents with lower levels of education feel that they cannot help their children learn certain subjects and deal with the necessary technology. Problems related to the use of internet/e-learning are quite large. Network connections and technical errors, such as downtime and server errors, hinder successful learning. Not to mention problems related to the balance of accessibility, for example, in villages and remote areas where the internet is difficult to reach. The facilities used are no longer classrooms but the availability of the internet and necessary equipment such as laptops, cellphones, quotas, and internet networks. It is a new problem in distance learning. The problem now is that the Indonesian education system faces these situations and conditions. Both teachers and students must master distance learning, the student learning process, without face-to-face communication with subject teachers in class. PJJ is a challenge for teachers to change their views and see that students can learn independently. In this case, it is hoped that students will better understand the problem-solving process and become more independent in learning so that students are expected to become more skilled. In distance learning, teachers must be more innovative and creative in packaging learning to create a fun learning for students (Asang, 2021; Mahmudah, 2021). When the teacher has good skills in packaging learning, of course, students will more easily understand the lesson and not feel bored with the learning given even though it is far away.

The implementation of distance learning will run well if there is cooperation between the school, parents, and the child himself. As parents, they will carry out this task even though they know that there will be many obstacles, such as the lack of skill of parents in using technology, the busyness of parents at work, and children's interest in learning which cannot be conditioned considering that many of their parents are busy working. If the child's interest in learning gradually decreases, it can reduce his learning achievement. So that parents are expected to provide assistance and strengthen learning as a form of cooperation in improving student achievement. Teachers must inspire and provide encouragement and strengthen students' potential, foster independence (activity) and creativity (creativity), so that dynamics can occur in the teaching process. Reinforcing the learning process seems very simple, but if the teacher does not do this, it isn't easy to properly understand the meaning of this kind of reinforcement because the right reinforcement reward can motivate students to learn. Giving correct reinforcement is done by doing good reinforcement, having a program to guide children to do a series of behaviors. The behavior is close to the expected behavior to achieve their learning goals.

Reinforcement learning encourages an effort to improve certain behaviors that may be repeated. This reinforcement is a response that can be verbal or nonverbal. In learning, this 
reinforcement is expected to increase the enthusiasm of children to be more active in carrying out learning activities. Strengthening from parents is very important for children's development to meet expectations. Reinforcement is a skill that can change or improve a behavior's quality. Providing reinforcement can be through limb movement or through expressions that someone displays, in providing reinforcement, of course, by providing positive values to be developed properly. In providing reinforcement, rewards and punishments can affect the smooth reinforcement process. However, what needs to be considered in giving punishment is giving something positive to continue to arouse children's enthusiasm for learning. Positive reinforcement can be given to children, such as giving a smile, enthusiasm for learning, and awards when accompanying children to learn. When they succeed in solving learning problems they face, always give positive responses be warm to children. Reinforcement is all forms of action, both verbal and non-verbal. It is part of a behavior change. It aims to provide feedback on behavior.

In the learning process, this reinforcement must be given to encourage the development of positive behavior. In learning, when children are not active in these activities, it is very necessary to reinforce people who accompany children to learn. In using reinforcement, of course, one must pay attention to the right situation and time so that the reinforcement provided is also effective. The learning process will also be more conducive when children are always given the right reinforcement and can maintain children's interest in learning. The provision of appropriate reinforcement can motivate children to study harder so that children's learning outcomes are also satisfactory. The use of reinforcement in connection with classroom management activities is intended to create a favorable classroom climate for students to learn optimally. If the class conditions are favorable, students can obtain good learning outcomes and create goals from the learning process. Reinforcing has a goal that involves improving student learning skills. One of the goals of providing reinforcement is to increase attention and motivation to learn, control, and change students' negative behavior into positive ones and direct children's thinking. Reinforcement is a verbal or non-verbal response to student behaviors that aim to provide information or feedback to the recipient on his actions as a form of impulse or correction. So that it can be said, students tend to repeat actions that can be positive reinforcement and stop actions or actions that get negative reinforcement.

Student learning discipline is an effort to foster student awareness to always study well by its function as an organizational group and follow the existing rules. Discipline in the form of ethics in learning. Students' discipline problems, such as chatting during teaching and learning activities, sleeping when the teacher teaches, irregular classroom conditions can hinder and disrupt the learning process. Learning discipline is a form of compliance from all students to carry out their obligations in participating in learning activities on an ongoing basis to get changes in knowledge, attitudes, and skills in the learning process. Discipline in learning can create a spirit of respect for time so that too much time is not wasted, through discipline learning activities can also be carried out with more mature preparation in many ways (Dewi et al., 2019; Murniyetti et al., 2016; Tanto et al., 2019). The existence of learning discipline can make children more focused on learning, starting from setting a study schedule. Children are more consistent in learning. Learning patterns are also more organized and directed.

During normal learning, teachers encourage students to be more disciplined in participating in learning at school. However, during the COVID-19 pandemic, parents encourage students to be more disciplined and increase their interest in learning. Parents as children's companions in learning activities must have the ability to reinforce learning discipline (Hanifah \& Budiyono, 2021; Miftakhi \& Ardiansah, 2020; Septanti, 2015). Parents can arrange a study schedule at home, accompany children and always provide motivation when children start to get bored in learning. When parents provide positive encouragement when children do learning activities, it will certainly impact their learning outcomes. However, during this pandemic, there are many problems related to children's interest in learning. They prefer playing with friends or operating gadgets, and parents don't have much time to accompany their children to study, negatively impacting their learning outcomes. For children's learning activities while at home to run well, schools need to explain to parents and parents to provide children's support and guidance. If parents do not reinforce the form of guidance or motivation, it can lead to miscommunication in receiving learning. This study aimed to analyze the strengthening of learning to improve student learning discipline during the pandemic. 


\section{METHOD}

This study uses a qualitative method. Qualitative research is based on postpositivism or interpretive philosophy. This research method is used to examine the state of nature. The researcher is the key tool in collecting qualitative research data using a combination of data collection techniques from observation and interviews (Sugiyono, 2016). Research subjects are individuals who provide information related to existing research questions. The subjects in this study were the parents of students in the village of Segoroyoso. At the same time, the object of research in this study is activities related to strengthening learning during the distance learning period in the village of Segoroyoso. The data analysis technique uses the Miles and Huberman model which includes three stages, namely data reduction, data display, and conclusion drawing/verification. Data analysis was carried out with the help of Atlas.ti software version 8.

\section{RESULT AND DISCUSSION}

Result

Researchers conducted interviews with parents of students in the Segoroyoso village environment. This interview aims to discover how parents reinforce children so that while children study at home, they remain disciplined and responsible for their learning activities. The results of the joint interview with Mrs. TW explained that parents contribute to strengthening children to learning. Advice is always given so that the child is diligent in completing his obligations as a student. The form of reinforcement given is learning motivation. Children's responses when given motivation can respond well. As a parent, of course, in providing motivation, you must also look at the situation and condition of the child. As parents, the opportunity to accompany their children to learn is certainly very desirable for children. However, sometimes due to busy work, children are accompanied by tutors, and their learning is somewhat more regular. During a pandemic, of course, parents are also worried about their children's learning outcomes, so arranging a child's study schedule must also be done. In assisting, of course, parents follow the directions given by the class teacher through the WhatsApp group. Reinforcement that is more often used is through motivation. Students need reinforcement in their learning activities. With the reinforcement, they feel they get an award in learning. It can stimulate them to be more active and enthusiastic in carrying out their responsibilities in learning. Verbal reinforcement strengthens expressions or expressions with words of praise, such as motivation to study harder.

The interview was done with Mrs. Ep. The results of the interviews obtained are that parents of elementary school students always provide learning assistance, especially during a pandemic. In assisting children's learning, they always provide verbal reinforcement, which motivates children to be diligent in learning. The response of the child sometimes does not feel confident in his abilities. So as a parent, I encourage you to be more confident. The factor that makes children more confident and ready to complete their responsibilities is direct assistance from parents during children's learning activities. In addition, there is a motivation that is always inserted in every learning activity. In arranging the study schedule as much as possible, I took the time to accompany him to study. Usually, in the morning, it was mandatory to complete the school assignments given by the teacher, in completing the task, by the direction of the class teacher sent to the WhatsApp group of each class. Asynchronous learning is a self-study method. Through asynchronous to encourage learning. This learning can be through Google Classroom, YouTube, or WhatsApp groups, which are resources to support the power of asynchronous learning. Teachers and students interact through online applications and not face-to-face.

The interview was done with Mrs. SK. She is one of the parents of elementary school students in the Segoroyoso village. The results of the interviews obtained are that when accompanying children who study from home during the covid 19 pandemic, they always reinforce motivation, giving applause to children, or thumbs up when children complete their learning responsibilities well. It aims to raise the spirit of learning. When the child can solve the problem well, I will give additional questions to strengthen his understanding of the child's response. When given reinforcement, the child will show an expression of acceptance well. In providing reinforcement, you must also pay attention to many aspects, one of which is that the reinforcement provided can foster a sense of pleasure in the child. Do not let the reinforcement we provide will reduce the enthusiasm for learning. In the discipline of learning, of course, many factors influence one of them because there are gifts or punishments when studying, but the punishments here are positive for children. When providing learning assistance, it is adjusted to 
the directions given by the teacher through the WhatsApp group, so it is also necessary to provide a study schedule to suit learning activities at school. For example, in the morning to complete school assignments, in the evening for additional study. Students need reinforcement in their learning activities. With the reinforcement, they feel they get an award in learning to stimulate them to be more active and enthusiastic in carrying out their responsibilities in learning. Verbal reinforcement strengthens expressions or expressions with words of praise, such as motivating to be more active in learning. Non-verbal is reinforcement in gestures, touches, movements to approach students, activities, and symbols or signs such as thumbs up or applause.

Based on observations made when distance learning is carried out, parents provide verbal and non-verbal reinforcement. This observation was carried out at the students' homes in the Segoroyoso village environment who took part in distance learning. Based on observations, parents accompany children to study at home by providing direction to children in learning. As a parent who cares about the child's spirit, of course, always motivates to learn as a form of reinforcement to be more disciplined. It is done when the child is in a good mood. The child listens to the advice given by the parents. At that time, I saw the child's parents were giving enthusiasm in learning with various advice, where the child listened carefully to what the parents said to the child. The child also seemed happy with the enthusiasm given by his parents. In guiding children for distance learning, parents always motivate children. Children will experience boredom when studying at home. As parents consistently provide stimulus so that children are always active in learning. It can be seen that when parents give advice, at that time the child is bored with learning, the child's facial expressions show that the child accepts the advice given by his parents. For children to be disciplined, parents also make learning rules at home during the distance learning period. Based on observations made at Mrs. TW's home, in studying while at home before studying with the accompanying teacher, the parents gave the rules first. When the accompanying teacher explains that children should not play alone, children must follow the study schedule at home that the teacher has given. Before finishing all school assignments on that day, the child may not play. Because of the accompanying teacher to study at home, it is easier for children to obey the rules from school or those made by parents at home.

Discipline is very important when in a distance learning condition. Seen children obey the rules of their parents. In the morning children learn like when children study at school, by completing the tasks given by the teacher. When it's time for a child to study and not study, in the afternoon, the child is given a sanction two times to go to the Koran, namely after Asr and after Maghrib. Based on observations at Mrs. SK's home, it was found that parents also provide learning rules for their children. In learning, parents rule that the child must listen when explaining. The child must not play before completing the task given by the teacher. Before studying, children should have breakfast to concentrate well while studying.

As a form of learning discipline in participating in distance learning, several responses from children are: children pray before and after studying, during distance learning due to the pandemic, children are accompanied by their parents in studying. Every child starts learning. The child is taught by his parents to pray before studying so that God will make it easier for him to learn. After finishing studying, children are also guided to read prayers after studying. In addition, children also pay attention when parents explain because children study at home. Parents as learning guides explain some of the teaching materials distributed by teachers so that children can easily understand the lessons given online. It was seen that the children were paying close attention when their parents were explaining the lesson material that day. Children can immediately understand what is conveyed by their parents. It looks like the children are happy with the explanation from their parents. In addition, the form of response to the reinforcement given is to do all the tasks from the teacher. Parents guide their children to complete the work assigned by the teacher every day. The child does and completes the task given by the teacher on the same day. It is not uncommon for children to find difficulties in solving these tasks in doing tasks. Like when I observe a child in learning, he finds it difficult to do the questions. It is because they have not been able to understand the question well, so in finding answers, they have difficulty. But the child was finally able to solve the difficulty thanks to his parents' help and encouragement so that children could submit assignments on time. At the time of distance learning, students collect assignments either online or offline by adjusting to the schedule provisions of the class teacher. In collecting assignments, some are collected through WhatsApp groups or via private messages on the teacher's WhatsApp. However, some assignments are submitted directly to the school, usually once a week or two weeks. The 
collection of assignments adjusts to the provisions that the school has given. The data processed using Atlas.ti version 8 software can be seen in Figure 1.

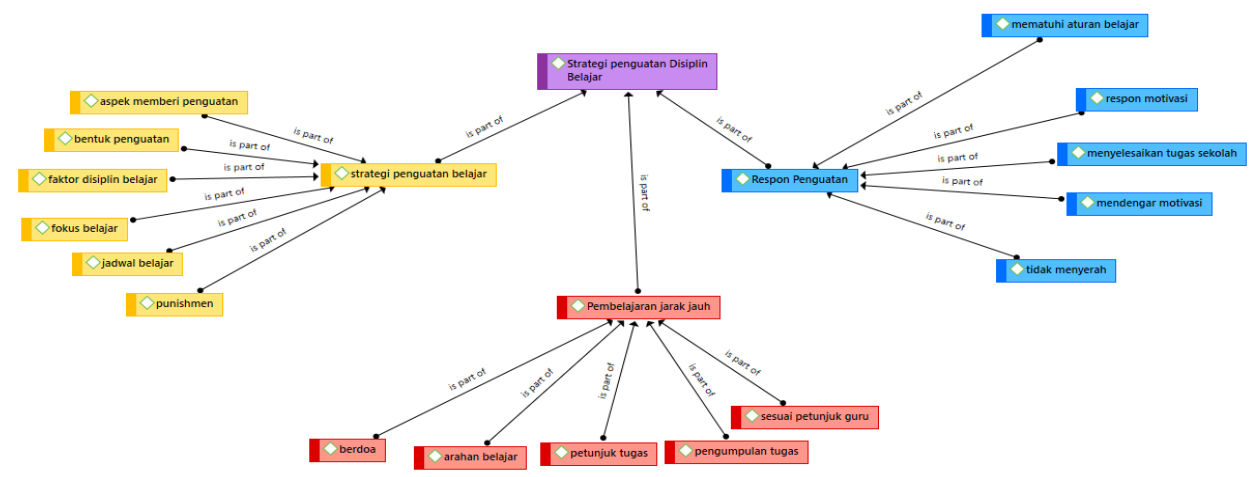

Figure 1. Data processed by Atlas.ti Software Version 8

\section{Discussion}

Students study at home with assistance from their respective parents during the distance learning period. So that the learning process goes well, parents will always reinforce it so that children are more enthusiastic about learning. The results of interviews and observations of parents daily reinforce children both verbally and non-verbally. The children can arouse the motivation to learn that is in them. Most parents provide verbal reinforcement. The verbal reinforcement given to children is with words of praise, you can do it, that's great. Parents who provide nonverbal reinforcement, such as giving children gifts, also give a thumbs up when the child succeeds.

Verbal reinforcement is reinforcement that is most often used. This reinforcement is usually in speech, flattery, support, stimulus, recognition. Non-verbal reinforcement is expressed by signs, such as the face and moving body parts, giving symbols or objects. There are two types of reinforcement, namely, verbal and non-verbal reinforcement. Verbal reinforcement is expressed with words of praise, while non-verbal reinforcement is done through gestures, approaches, and touch. In supporting the learning process, you can combine verbal and nonverbal reinforcement with leading to effective and communicative learning.

In providing reinforcement, parents must pay attention to aspects. As for the aspects that are considered by parents based on the results of interviews and observations, namely, seeing the situation and condition of the child, providing motivation that can generate selfconfidence, in providing reinforcement it must please the child. With parental reinforcement, children will be encouraged to be more disciplined during the learning process (Andriati et al., 2021; Prabowo et al., 2020; Purnomo \& Ningsih, 2020). Based on the observations and interviews, the factors that encourage children to be more disciplined are learning assistance from parents and giving gifts if the child is successful. Giving reinforcement is based on giving warmth, growing enthusiasm, meaning, and avoiding giving negative responses to children. If the child's response is positive reinforcement, a parent can give simple gifts that increase student enthusiasm. If children are given reinforcement but their discipline decreases, punishment can improve students. Rewards and punishments on student learning motivation have a very big influence. If students study hard, they will achieve an achievement that will positively impact students, increasing students' enthusiasm to learn (Ernata, 2017; Novitasari, 2019; Rahman, 2015).

The response is behavior that is influenced by reactions and environmental stimuli. Student response is a student's reaction or behavior after receiving certain stimuli during the learning process. In observing the observed object involving the five senses in the process, it can produce a response. Responses from students are needed to describe the weaknesses and strengths of the learning carried out. During the distance learning period, it is necessary to carry out further learning activities better. When a child is given reinforcement, there will be a response given by the child. The response can be in a smile or the emergence of selfconfidence from within the child. Based on the results of interviews and observations made, the response given by the child when parents reinforce while studying, the child accepts the advice with a smile, with pleasure the child shows a facial expression to accept the advice, and the child responds with action, namely completing the task immediately. When children find 
difficulties in learning, children do not give up quickly. Children try and always ask their parents because they can understand the problem to solve the problem in the end. During the distance learning period, parents make rules for their children so that learning from home is achieved and children are given rules in learning. Based on the interviews and observations of children's responses, they obey these rules when given learning rules. Children start learning at 07.30 after the teacher gives assignments. Children also listen to their parents' explanations well and are not hurry to complete assignments. Children also complete the tasks assigned by the teacher that day.

Based on interviews and observations, children study at home during the pandemic. Children get learning online. The school provides directions in learning in detail, either in photos, in writing, or in the form of videos. The directions are sent through the class WhatsApp group platform or google classroom. By the teacher's direction, before starting to learn, the child prays first and is guided by the parents who accompany the study (Irwandi \& Lusilawati, 2019; Yensy, 2020). In doing assignments from the teacher, children do assignments according to the instructions given via WhatsApp or google classroom. Parents also help provide explanations if children have learning difficulties. By the instructions from the teacher, the child collects assignments according to the teacher's instructions every day. Some assignments are sent in the form of photos or videos. If in written form in a notebook or assignment book, the collection is once a week or two weeks. The learning scheme used using WhatsApp guidance groups is done by sending a short video or text form, by watching TVRI television shows as a form of giving material. After watching, students are given assignments according to the questions on television, but sometimes the teacher also gives assignments. The main characteristic of distance learning is that students can independently explore the knowledge they want to know by using information technology.

\section{CONCLUSION}

Children need parents in the distance learning period during a pandemic like now. Parents have a responsibility to guide their children while learning from home. Parents must be able to discipline their children during learning activities. To discipline children, parents reinforce so that children are more enthusiastic about learning. Reinforcement provided by parents is verbal reinforcement, and some are in the form of nonverbal. Usually, in the form of verbal, parents motivate with words of praise. While in the non-verbal form, parents give applause or thumbs up. When parents give a reinforcement, the child's response is accepted well to complete the task well and obey the parent's learning rules. When the parent explains, the child listens well. The child collects assignments on time according to the directions from the school teacher given via WhatsApp group or google form.

\section{REFERENCES}

Alqudah, N. M., Jammal, H. M., Saleh, O., Khader, Y., Obeidat, N., \& Alqudah, J. (2020). Perception And Experience Of Academic Jordanian Ophthalmologists With E-Learning For Undergraduate Course During The Covid-19 Pandemic. Annals Of Medicine And Surgery, 59(June), 44-47. https://doi.org/10.1016/j.amsu.2020.09.014.

Andriati, N., Martin, M., Atika, A., \& Hidayati, N. W. (2021). Pelatihan Dan Pendampingan Sistem Pembelajaran Kepada Orang Tua Siswa Sekolah Dasar Kubu Raya. Jurnal IImiah Pangabdhi, 7(2). https://doi.org/10.21107/pangabdhi.v7i2.11785.

Asang, D. (2021). Upaya Kepala Sekolah Meningkatkan Kemampuan Guru Menggunakan Fasilitas Voice Note Whatsapp Sebagai Media Pembelajaran Jarak Jauh Melalui Kegiatan Pendampingan Di Upt Smk Negeri 8 Luwu. Dida, 9(4), 439-450. https://jurnaldidaktika.org/contents/article/view/58.

Dewi, A. K. T., Degeng, I. N. S., \& Hadi, S. (2019). Implementasi Pendidikan Nilai Karakter Di Sekolah Dasar Melalui Budaya Sekolah. Jurnal Pendidikan: Teori, Penelitian, Dan Pengembangan, 4(2), 247-255. https://doi.org/10.17977/jptpp.v4i2.12011.

Ernata, Y. (2017). Analisis Motivasi Belajar Peserta Didik Melalui Pemberian Reward Dan Punishment Di Sdn Ngaringan 05 Kec.Gandusari Kab.Blitar. Jurnal Pemikiran Dan Pengembangan Sekolah Dasar (Jp2sd), 5(2), 781-790. https://doi.org/10.22219/jp2sd.vol5.no2.781-790.

Hanifah, N., \& Budiyono, A. (2021). Pendampingan Orang Tua Untuk Mendisiplinkan Anak Belajar Selama Masa Pandemi. Ghaidan, 5(1), 1-15. https://doi.org/10.19109/ghaidan.v5i1.6458. 
Hignasari, L. V., \& Supriadi, M. (2020). Pengembangan E-Learning Dengan Metode SelfAssessment Untuk Meningkatkan Hasil Belajar Matematika Mahasiswa Universitas Mahendradatta. Jurnal Kependidikan, 6(2), 206-219. https://doi.org/10.33394/jk.v6i2.2476.

Irwandi, I., \& Lusilawati, L. (2019). Efektivitas Pembelajaran Daring Melalui Whatsapp Terhadap Minat Dan Hasil Belajar Biologi. Bioedusains: Jurnal Pendidikan Biologi Dan Sains, 4(2). https://doi.org/10.31539/bioedusains.v4i2.2519.

Latifah, A., \& Prastowo, A. (2020). Analisis Pembelajaran Daring Model Website Dan MLearning Melalui Youtube Pada Mata Pelajaran Pai Kelas 2 Sd/Mi. Jurnal Limas Pgmi, 1(1). http://jurnal.radenfatah.ac.id/index.php/limaspgmi/article/view/7304.

Mahmudah, F. N. (2021). Self-Innovation Guru Dalam Meningkatkan Prestasi Siswa Pada Masa Pandemi Covid-19. Ta'dibuna: Jurnal Pendidikan Islam, 10(1), 119. https://doi.org/10.32832/tadibuna.v10i1.4075.

Miftakhi, D. R., \& Ardiansah, F. (2020). Peranan Orang Tua Siswa Dalam Melaksanakan Pendampingan Pembelajaran Dari Rumah Secara Online. Joeai (Journal Of Education And Instruction), 3(2), 151-158. https://doi.org/10.31539/joeai.v3i2.1726.

Murniyetti, M., Engkizar, E., \& Anwar, F. (2016). Pola Pelaksanaan Pendidikan Karakter Terhadap Siswa Sekolah Dasar. Jurnal Pendidikan Karakter, 6(2), 156-166. https://doi.org/10.21831/jpk.v6i2.12045.

Novitasari, A. (2019). Pemberian Reward And Punishment Dalam Membentuk Karakter Disiplin Anak Pada Sekolah Madrasah Ibtidaiyah. Halaqa: Islamic Education Journal, 3(1), 2733. https://doi.org/10.21070/halaqa.v3i1.2113.

Prabowo, S. H., Fakhruddin, A., \& Rohman, M. (2020). Peran Orang Tua Dalam Pembentukan Karakter Anak Di Masa Pandemi Covid-19 Perspektif Pendidikan Islam. Al-Tadzkiyyah: Jurnal Pendidikan Islam, 11(2), 191-207. https://doi.org/10.24042/atjpi.v11i2.7806.

Purnomo, E. H., \& Ningsih, T. (2020). Peran Orang Tua Dalam Mendampingi Anak Belajar Selama Pandemi. Jurnal Kependidikan, 8(2), 235-248. https://doi.org/10.24090/jk.v8i2.4712.

Rahman, M. M. (2015). Upaya Orang Tua Dalam Membimbing Remaja. Jurnal Bimbingan Konseling Islam, 6(1), 41-62. https://journal.iainkudus.ac.id/index.php/konseling/article/view/1039/951.

Santosa, F. H., Negara, H. R. P., \& Samsul Bahri. (2020). Efektivitas Pembelajaran Google Classroom Terhadap Kemampuan Penalaran Matematis Siswa. Jurnal Pemikiran Dan Penelitian Pendidikan Matematika (Jp3m), 3(1), 62-70. https://doi.org/10.36765/jp3m.v3i1.254.

Septanti, E. (2015). Peranan Keluarga Dalam Proses Penanaman Kedisiplinan Terhadap Remaja Di Dusun Krajan, Desa Gembong, Kecamatan Arjosari, Kabupaten Pacitan Tahun 2015. Citizenship: Jurnal Pancasila Dan Kewarganegaraan, 4(1). http://ejournal.unipma.ac.id/index.php/citizenship/article/view/1089/951.

Sugiyono. (2016). Metode Penelitian Kualitatif, Kuantitatif, Dan R\&D. Alfabeta.

Tanto, O. D., Hapidin, H., \& Supena, A. (2019). Penanaman Karakter Anak Usia Dini Dalam Kesenian Tradisional Tatah Sungging. Jurnal Obsesi: Jurnal Pendidikan Anak Usia Dini, 3(2), 337. https://doi.org/10.31004/obsesi.v3i2.192.

Wang, Z., Duan, Y., Jin, Y., \& Zheng, Z.-J. (2020). Coronavirus Disease 2019 (Covid-19) Pandemic: How Countries Should Build More Resilient Health Systems For Preparedness And Response. Global Health Journal, 4(4), 139-145. https://doi.org/10.1016/j.glohj.2020.12.001.

Widiastuti, Y. K. W., Rasmani, U. E. E., \& Wahyuningsih, S. (2020). Mengkaji Penerapan ELearning Pada Anak Usia Dini. Jurnal Obsesi: Jurnal Pendidikan Anak Usia Dini, 5(2), 1240-1247. https://doi.org/10.31004/obsesi.v5i2.752

Widyantara, I., \& Rasna, I. (2020). Penggunaan Media Youtube Sebelum Dan Saat Pandemi Covid-19 Dalam Pembelajaran Keterampilan Berbahasa Peserta Didik. Jurnal Pendidikan Dan Pembelajarna Bahasa Indonesia, 9(2). https://ejournalpasca.undiksha.ac.id/index.php/jurnal_bahasa/article/view/3531.

Yensy, N. A. (2020). Efektifitas Pembelajaran Statistika Matematika Melalui Media Whatsapp Group Ditinjau Dari Hasil Belajar Mahasiswa (Masa Pandemik Covid 19). Jurnal Pendidikan Matematika Raflesia, 05(02), 65-74. https://doi.org/10.33449/jpmr.v5i2.11410. 